Reprod. Nutr. Dévelop., 1980, 20 (6), 1739-1749.

\title{
Development and initiation of sperm motility in the hamster epididymis
}

\author{
par Marie-Louise KANN, Catherine SERRES *
}

\author{
Physiologie de la Reproduction des Vertébrés, Bât. A, \\ Université $P$. ef $M$. Curie \\ 4, Place Jussieu, 75230 Paris Cedex 05. \\ * Laboratoire d'Histologie-Embryologie, Cytogénétique \\ Centre Hospitalier de Bicêtre, 78 rue du Général Leclerc \\ 94270 Kremlin-Bicêtre, France.
}

\begin{abstract}
Summary. Hamster spermatozoa were isolated from the caput, corpus and cauda epididymidis. They were observed in culture medium at $37^{\circ} \mathrm{C}$ with a phase-contrast microscope and their motility recorded cinematographically. About 20 p. 100 of the caput epididymidis spermatozoa were motile and moved in a confined space with no forward progression. 30 p. 100 of the corpus epididymidis spermatozoa were motile, showing increased flagellar activity and moving in wide circles. 90 p. 100 of the cauda epididymidis spermatozoa were motile and moved forward. Forward motility was induced in immotile spermatozoa from the caput epididymidis by adding cyclic $3^{\prime}-5^{\prime}$ adenosine monophosphate (cAMP) phosphodiesterase inhibitors (caffeine, theophylline, $I M X$ ) and epididymal plasma. The best stimulation was initiated by $15 \mathrm{mM}$ caffeine with 10 p. 100 of cauda epididymal plasma; a mean of $60 \mathrm{p}, 100$ of forward motility was obtained wich lasted for one hour and then ceased. Cinematographic studies revealed that some induced sperm movements differed from the equivalent natural ones by the amplitude of the head movements. It is shown that during epididymal transit of hamster spermatozoa, the induction of forward motility requires not only an increased cAMP level but also factors from the cauda epididymal plasma. The idea that glycoprotein of epididymal origin initiates forward motility is discussed.
\end{abstract}

\section{Introduction.}

Mammalian spermatozoa acquire the ability to move forward and to fertilize during epididymal maturation. This fertilizing ability is achieved through maturation in the epididymis and capacitation in the female genital tract, but the mechanism of spermatozoon motility induction is still unknown.

Recent biochemical studies, mainly in the bovine epididymis, have shown that the development of motility form the caput to the cauda epididymidis could involve several simultaneous processes (Hoskins, Brandt and Acott, 1978).

In the first process, the intrasperm level of cyclic AMP increases during epididymal transit. The concentration of cyclic AMP phosphodiesterase, which degrades the active AMP $3^{\prime}-5^{\prime}$ into inactive $5^{\prime}$, is higher in spermatozoa from the caput epididymidis than in 
those from the cauda (Stephens, Wang and Hoskins, 1979). The decline of this enzyme activity during epididymal transit increases ATPase activity, and is supposed to be the essential cellular factor inducing sperm motility (Garbers et al., 1971 ; Garbers, First and Lardy, 1973 ; Garbers ef al., 1973 ; Hoskins, Stephens and Hall, 1974 ; Cascieri, Amann and Hammerstedt, 1976).

In the second process, a specific glycoprotein, which may induce forward movement, could bind to the spermatozoa. This glycoprotein seems to be present in the testicular, epididymal and seminal fluids (Hoskins, Hall and Munsterman, 1975 ; Brandt ef al., 1978 ; Acott et al., 1979). Several ultrastructural investigations have noted an increase in the negative surface charge and in concanavalin-A receptors on the surface of the plasma membrane of spermatozoa passing through the epididymis in the rabbit (Gordon, Dandekar and Bartoszewicz, 1974, 1975 ; Fléchon, 1975) and in the rat (Fournier-Delpech, Danzo and Orgebin-Crist, 1977). These studies could be related to the initiation of forward motility. However, recent ultrastructural data on the rabbit (Nicolson et al., 1977) and the ram (Courtens et Fournier-Delpech, 1979) have shown no variation in concanavalin-A affinity for the plasma membrane of the spermatozoa during their epididymal transit.

Once the spermatozoa have acquired the capacity to move, the need for calcium ion might be the third factor required for the initiation of sperm motility Earlier studies seem to show that the presence of calcium ion is not always necessary, depending on the species. Rodent spermatozoa apparently need calcium for motility initiation (Morton ef al., 1974). Furthermore, the degree of sperm motility appears to be proportional to the free calcium level found in the cauda epididymis sperm (Morton et al., 1978). Few studies have been done on farm animals, but bull spermatozoa do not seem to require the presence of calcium ion for motility (Hoskins, Brandt and Acott,1978).

The present investigation describes the in vitro motility pattern observed for hamster spermatozoa harvested from the caput, corpus and cauda epididymis. In addition, forward motility was induced in immotile caput spermatozoa by raising the intracellular CAMP level with phosphodiesterase inhibitors in the presence of epididymal plasma.

\section{Material and methods.}

1. Preparation of sperm suspensions. - Mature 2 to 5 -month old hamster males were anesthesized with pentobarbital. The epididymides were divided into three distinct segments : the caput, corpus and cauda. The spermatozoa from each segment were oblained by cutting the tissue with a razor blade. The tubules were immersed in a few drops of the in vitro $B_{2}$ culture medium (Ménézo, 1976), and squeezed to obtain their contents. By dilution in the same medium, the final sperm concentration was adjusted to about $2.10^{7} / \mathrm{ml}$.

2. Motility measurement. - Three animals were used to measure each motility pattern. One drop of the sperm suspension was immediately placed on an hemocytometer slide (depth : $0.1 \mathrm{~mm}$ ). The preparation was maintained at $37^{\circ} \mathrm{C}$ and examined by phasecontrast microscopy. Observations were recorded cinematographically on moving film taken at a speed of fifty frames per sec. The films obtained were projected frame 
by frame. Depending on the experiment, the percentage of motile spermatozoa was determined by counting about 200 to 400 cells per animal, and each epididymal segment was analyzed, The positions of 10 to 15 motile spermatozoa per sample were drawn on paper for $1 \mathrm{sec}$, and the mean velocity was calculated. We preferred not to use a forward motility index since the index is obtained by the integration of the two parameters (velocityand percentage of motile spermatozoa) which we have separately and truly measured by microcinematography.

3. Induction of motility. - The spermatozoa from the caput epididymidis were recorded by the method described above. Their final concentration was approximately $2.10^{7} / \mathrm{ml}$ in the $B_{2}$ medium.

Extraction of epididymal plasma. - The cauda epididymides were removed and punctured in several places with a needle. Exudation of the contents was obtained by pressure on the epididymis. The undiluted epididymal contents were taken up in hematocrit fubes $(75 \mathrm{~mm}$ long $\times 1.1 \mathrm{~mm}$ ID) which were then sealed at one end in a flame and centrifuged for $10 \mathrm{~min}$ at $20^{\circ} \mathrm{C}$ in a microhematocrit centrifuge. The tubes were broken at the junction between the epididymal plasma and the sperm pellet which was discarded. $0.1 \mathrm{ml}$ of epididymal plasma was diluted in $0.9 \mathrm{ml}$ of $B_{2}$ medium mixed with a Pasteur pipette.

Phosphodiesterase inhibitors. - Caffeine was added to the sperm suspension as $0.1 \mathrm{M}$ solution dissolved in $B_{2}$ medium so that the scale of final inhibitor concentrations was graduated from 3 to $15 \mathrm{mM}$. In the same way, a scale of theophylline concentrations from 10 to $30 \mathrm{mM}$ and a scale of 3 isobuthyl-1-methylxanthine (IMX) concentrations from 1 to $7 \mathrm{mM}$ were obtained. The $B_{2}$ medium was used for its high concentration in $\mathrm{Ca}^{++}(1.5$ to $3 \mathrm{mM})$, glucose $(1.2 \mathrm{mg} / \mathrm{ml})$ and bovine albumin $(10 \mathrm{mg} / \mathrm{ml})$. The incubations were carried out at $37^{\circ} \mathrm{C}$. Epididymal plasma was used at a 10 p. 100 concentration.

\section{Results.}

1. Development of motility.

Caput epididymidis spermatozoa. - About 20 p. 100 of the spermatozoa showed movement by phase-contrast microscopy. The microcinematographic studies confirmed this estimate and showed several motility patterns (table 1). On one pattern (table $1 \mathrm{~A}$ ), the spermatozoon movements were limited to a confined space. The heads

TABLE 1

Spermatozoa from the caput epididymidis. Results obtained by microcinematographic study

\begin{tabular}{|c|c|c|c|c|}
\hline \multirow{2}{*}{$\begin{array}{l}\text { Number of } \\
\text { spermatozoa } \\
\text { observed }\end{array}$} & \multirow{2}{*}{$\begin{array}{c}\text { Motile } \\
\text { spermatozoa }\end{array}$} & \multicolumn{3}{|c|}{ Different motility patterns } \\
\hline & & $A$ & B & $c$ \\
\hline $\begin{array}{l}\qquad 65 \\
\text { Progression velocity }(\mu / \mathrm{sec})\end{array}$ & $\begin{array}{c}83 \\
(22 \text { p. } 100)\end{array}$ & $(14$ p. 100) & $\begin{array}{c}18 \\
(5 \mathrm{p} .100) \\
-\end{array}$ & $\begin{array}{c}10 \\
(3 \text { p. } 100) \\
58.5 \pm 5.9\end{array}$ \\
\hline
\end{tabular}




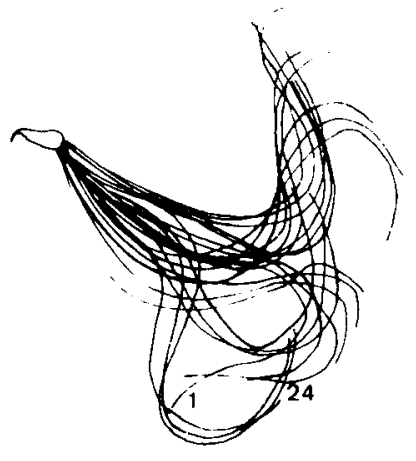

1

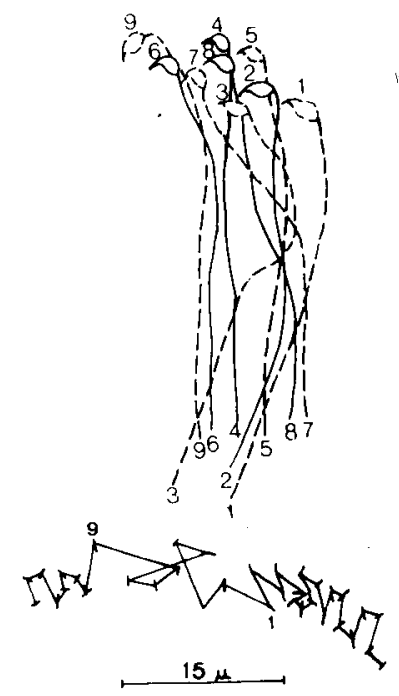

3
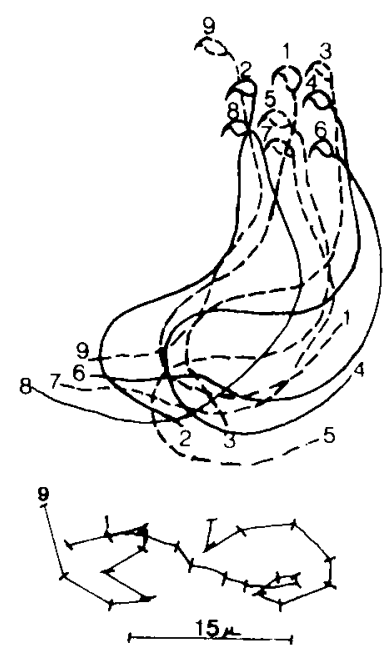

2
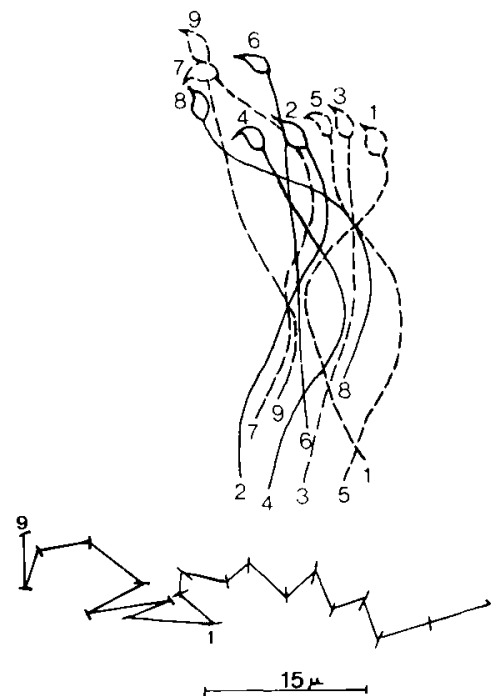

4

\section{PLATE I}

Successive positions of spermatozoa at 0.02 -sec intervals. Path followed by spermatozoon head and tail position in successive frames.

FIG. 1. - Caput epididymidis spermatozoa. A lone flagellum swings. Fig. 2. - Caput epididymidis spermatozoa. Note wide amplitude of flagellum curvature. Fig. 3. - Corpus epididymidis spermatozoa. The majority of spermatozoa move in large circles. Amplitude of flagellum curvature is smaller. Fig. 4. - Forward moving spermatozoa from the cauda epididymidis progress in a straight line. 
did not describe simple geometric figures and the tails were incurved. In another pattern (table $1 \mathrm{~B}$ ), the spermatozoon head did not move but the flagellum swung (Plate I, fig. 1). The third pattern (table $1 \mathrm{C}$ ) represents spermatozoa which progressed irregularly (Plate I, fig. 2). The amplitude of the tail curvature was very wide, causing the large movement of the spermatozoon head. The calculated mean velocity was $58.5 \mu / \mathrm{sec}$.

Corpus epididymidis spermatozoa. - The spermatozoa were less numerous. Several motility patterns were observed. The motility of some was similar to that of caput epididymidis spermatozoa, but the rate of flagellar movement was increased and the spermatozoa moved in very wide circles (Plate I, fig. 3 ). The mean diameter of these circles, calculated from 14 circular trajectories, was $62 \mu \pm 5.3$. Generally, the spermatozoon head did not rotate, but the flagellum vibrated rapidly and was less curved than in the type of movement described in the caput epididymidis (Plate I, fig. 2). This population represented the majority of motile spermatozoa from the corpus. Yet, a few spermatozoa moved forward. The percentage of motile spermatozoa in this region was about 30 p. 100.

Cauda epididymidis spermatozoa. - 90 p. 100 of the spermatozoa were motile. Two types of motility - circular and forward - were observed. The percentage of each motility pattern varied with the sample. The circular movement was similar to the one described above (Plate I, fig. 3). The forward moving spermatozoa rotated around their great axis and progressed rapidly in straight trajectories. The tail curve had a small amplitude (Plate I, fig. 4) and the tail seemed stiffer than that of the caput epididymidis spermatozoa. The progressive velocities, calculated from different samples of cauda epididymidis spermatozoa (table 2), showed a mean forward motility of $294 \mu / \mathrm{sec}$.

TABLE 2

Forward progression velocify of cauda epididymidis spermatozoa measured by microcinematography

\begin{tabular}{|c|c|c|}
\hline & n & Average velocity $(\mu / \mathrm{sec})$ \\
\hline Hamster $1 \ldots . . .$. & 15 & $\begin{array}{c}254.8 \pm 21.4^{*} \\
(152-491)\end{array}$ \\
\hline Hamster $2 \ldots . . .$. & 16 & $\begin{array}{c}344 \pm 13.8 \\
(275-482)\end{array}$ \\
\hline Hamster $3 . . . . .$. & 15 & $\begin{array}{c}281.1 \pm 10.5 \\
(206-344)\end{array}$ \\
\hline
\end{tabular}

* Standard deviation $\left(\frac{S}{\sqrt{n}}\right), n=$ number of spermatozoa analysed.

2. Induction of motility.

Induction with phosphodiesterase inhibitors only. - After incubation at $37^{\circ} \mathrm{C}$ in $\mathrm{B}_{2}$ medium, several cyclic AMP phosphodiesterase inhibitors induced motility in caput sperm without significant forward progression. 
When theophylline was used, the best result was obtained at a $30 \mathrm{mM}$ concentration. This level initiated a twitching movement in approximately 30 p. 100 of the spermatozoa with a peak activity occurring within $15 \mathrm{~min}$. Motility was initiated 4 min after the beginning of incubation and was lost $30 \mathrm{~min}$ later. Decreasing the theophylline levels to $10 \mathrm{mM}$ stimulated a lower activity and required a longer incubation time (fig. 1).

The caffeine assays are shown in figure 2 . The best activation was obtained at a concentration of $15 \mathrm{mM}$ (up to 60 p. 100 motility). Lower concentrations (12 to $3 \mathrm{mM}$ ) showed gradually decreasing activity response; in most cases, no activity was observed below $3 \mathrm{mM}$. Activity response occurred $3 \mathrm{~min}$ after the beginning of incubation; peak activity was noted $20 \mathrm{~min}$ later and lasted $1 \mathrm{hr}$.

The optimal concentration of 3-isobuthyl-1-methyl-xanthine (IMX) was $7 \mathrm{mM}$. Stimulation was not observed before $10 \mathrm{~min}$ of incubation ; peak activity occurred around $25 \mathrm{~min}$ and decreased rapidly after $30 \mathrm{~min}$ of incubation (fig. 3).
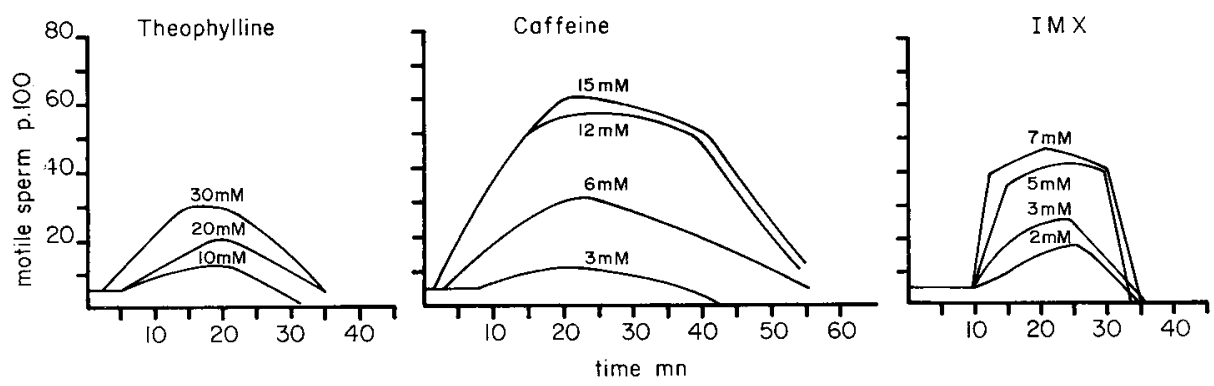

FIG. 1, 2, 3. - Initiation of caput epididymidis spermatozoa motility by varying concentrations of different phosphodiesterase inhibitors : theophylline, caffeine, IMX. The percentage of motile spermalozoa was calculated for each initiation by observation of a mean of 900 cells from 3 animals.

In all the cases studied, we observed the same pattern of motility initiation : the spermatozoa started to move in wide circles. The motion induced by caffeine was more vigorous and coordinated than that induced by theophylline or IMX. In all the cases, the three inhibitors stimulated only very little forward progression.

Induction with phosphodiesterase inhibitors and cauda epididymidis plasma. - Earlier studies have shown that the presence of some glycoproteins in the fluids of the male genital tract could be a necessary factor in the initiation of forward motility (Brandt et al., 1978 ; Acott et al., 1979). In our experiment, forward motility was successfully induced in most cases by adding a 10 p. 100 concentration of cauda epididymidis plasma to the phosphodiesterase inhibitors.

$7 \mathrm{mM}$ IMX (figs. 4, 5) and $30 \mathrm{mM}$ theophylline (figs. 6, 7) stimulated forward motility in less than 30 p. 100 of the spermatozoa. No stimulation was observed after $40 \mathrm{~min}$.

The best stimulation was obtained with $15 \mathrm{mM}$ caffeine (figs. 8, 9). The mean percentage of flagellating spermatozoa observed after incubation at $37^{\circ} \mathrm{C}$ was approximately 80 p. 100 , with 60 p. 100 moving forward. The activation decreased with time : we could not stimulate the spermatozoa after $60 \mathrm{~min}$.

The spermatozoa stimulated with $15 \mathrm{Mm}$ caffeine and 10 p. 100 of caudal plasma were analyzed by microcinematography. They showed two motility patterns. 

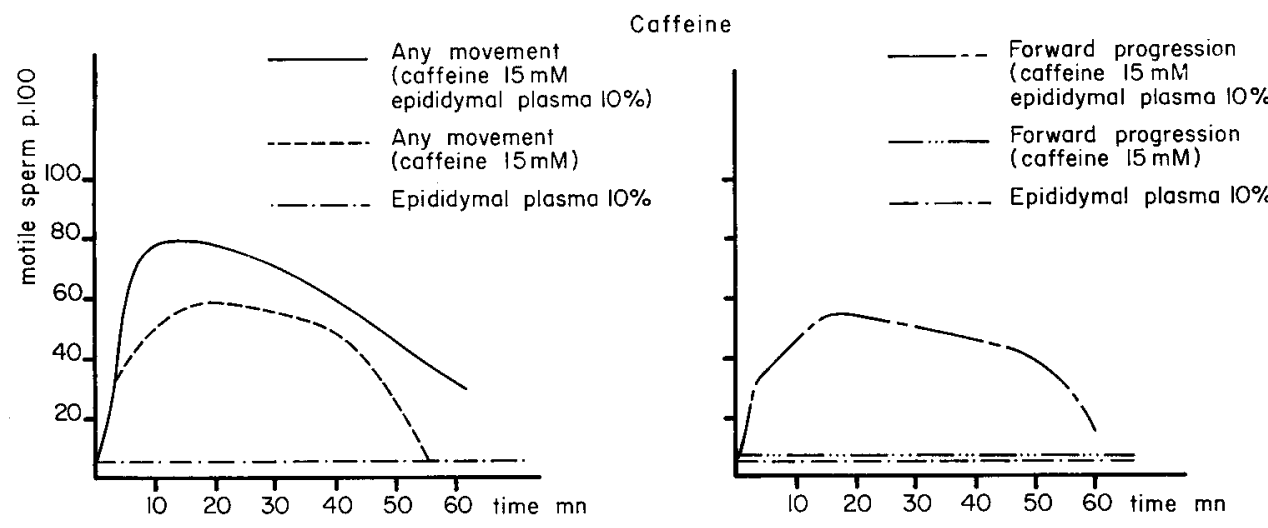

FIG. 4, 5. - Initiation of caput epididymidis spermatozoa motility by $7 \mathrm{mM} \mathrm{IMX}$ and 10 p. 100 caudal plasma. Fig. 4 shows the percentage of spermatozod with any movement. Fig. 5 shows the percentage of spermatozoa with forward progression.

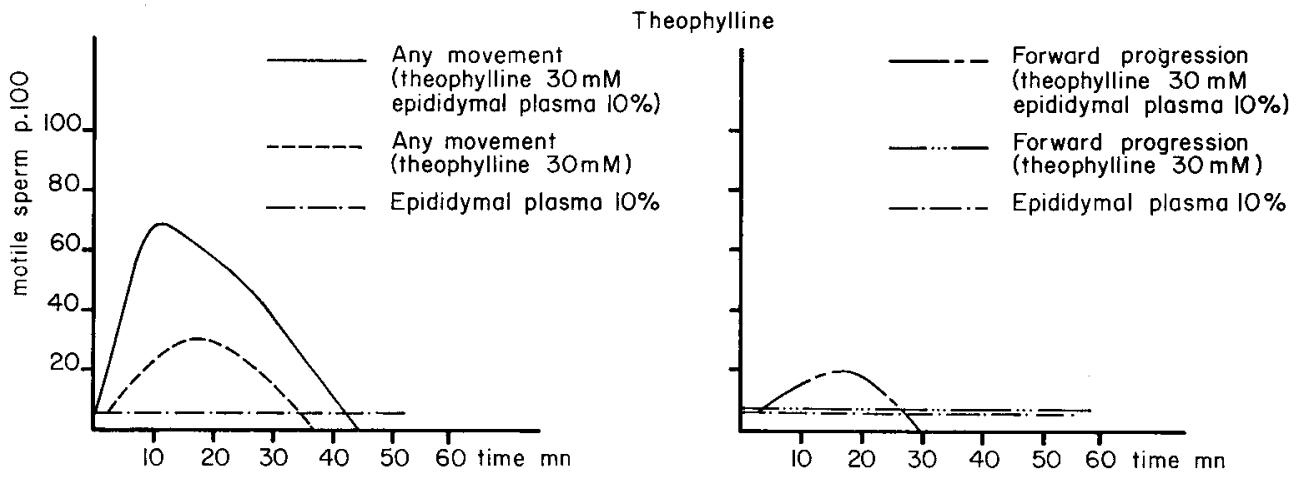

FIG. 6, 7. - Initiotion of caput epididymidis spermatozoa motility by $30 \mathrm{mM}$ theophylline and $10 \mathrm{p} .100$ of caudal plasma. Fig. 6. - shows the percentage of spermatozoa with any movement. Fig. 7 . shows the percentage of spermatozoa with forward progression.
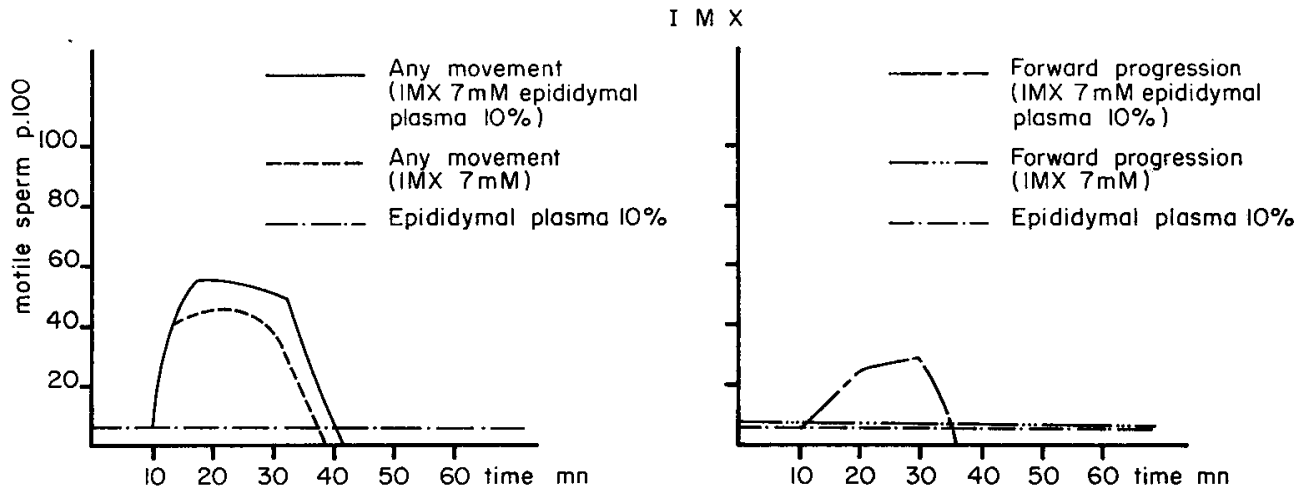

FIG. 8, 9. - Initiation of caput epididymidis spermatozoa motility by $15 \mathrm{mM}$ caffeine and 10 p. 100 of caudal plasma. Fig. 8 shows the percentage of spermatozoa with any movement. Fig. 9 shows the percentage of spermatozon with forward progression. 
a) Irregular-circular motility. - The spermatozoa moved in circles, showing motility similar to that of the corpus epididymidis spermatozoa, but the mean diameter of the orbit was significantly smaller $(31.2 \mu \pm 2.1$, calculated from 9 trajectories), as verified by Student's t-test $(P<0.001)$, and the amplitude of the head movement was wider (Plate II, figs. 1, 2).

b) Induced progressive motility. - Microcinematography revealed two progressive motility patterns which we had not seen with phase-contrast microscopy. One represented slower moving spermatozoa (Plate II, figs. 3, 4), and the other, spermatozoa with wide, lateral head movements (Plate II, figs. 5, 6).

The percentage of forward moving spermatozoa increased between 5 and 20 min after the beginning of incubation at $37^{\circ} \mathrm{C}$. Their velocity was maximal at $10 \mathrm{~min}$ $(239.5 \mu / \mathrm{sec} \pm 19.1)$, less at $15 \mathrm{~min}(117.5 \mu / \mathrm{sec} \pm 13.5)$ and then decreased slowly after $20 \mathrm{~min}$. At $10 \mathrm{~min}$, these velocities were not very different from those calculated for the cauda epididymidis samples.

Between $30 \mathrm{~min}$ and $1 \mathrm{hr}$, the spermatozoa lost their forward progression, but regained their circular movement just before all motility ceased.

\section{Discussion.}

The motility patterns of hamster spermatozoa gradually changed as the spermatozoo travelled through the epididymis.

The caput epididymidis spermatozoa did not move at all or moved slowly, but could not move forward.

The flagellating movements changed progressively as the spermatozoa travelled from the caput of the cauda epididymidis. Deficient, partial, vibratory movement was transformed into intermediate circular movement, ending with a quick, full-forward movement.

Earlier studies in many species have reported similar observations (for review see Gaddum, 1968). The potential for forward motility occurs as the spermatozoa pass through the epididymis, and the capacity for forward movement is acquired in different regions of that organ, depending on the species studied.

Hamster spermatozoa from the caput epididymidis display a motility similar to that of the capacitated spermatozod described by Yanagimachi (1970). After in vitro capacitation in the hamster, that author observed spermatozoon movements with the same flagellating amplitude that we noted in caput epididymidis spermatozoa (Plate I, fig. 2). These data suggest that during epididymal maturation, the membrane of the spermatozoon tail acquires new properties which may play a role in initiating the forward movement. Capacitation may mean a loss of these properties, which could explain the modifications in the motility pattern in the female genital tract.

The best induction of motility in caput epididymidis spermatozoa was obtained with caffeine. As compared to the other two phosphodiesterase inhibitors, caffeine stimulated vigorous motility over a longer period of time. Its initiation required a higher concentration than the one needed to stimulate cauda epididymis spermatozoa (Morton and Chang, 1973 ; Paz et al., 1978 ; Fraser, 1979). 


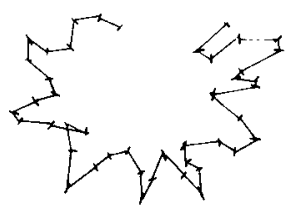

Iig 1
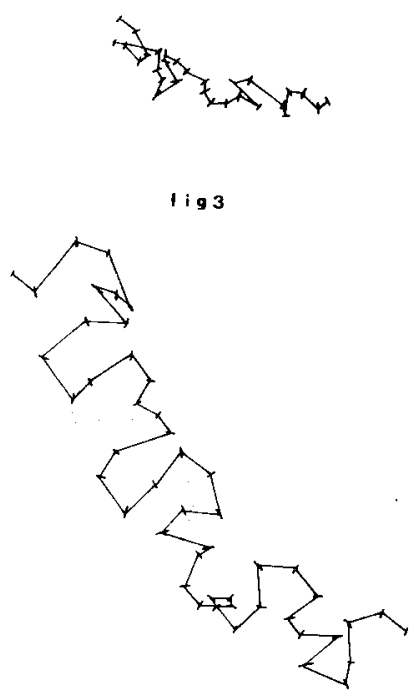

1 ig 3

fig 5

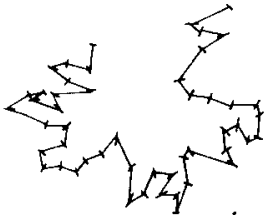

1 i $g 2$
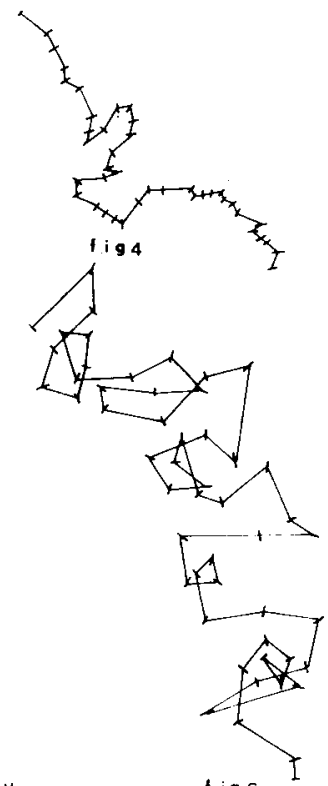

$\operatorname{lig} 6$

PLATE II

Successive positions of caput spermatozoa at 0.02-sec intervals. Stimulation with $15 \mathrm{mM}$ caffeine and $10 \mathrm{p} .100$ of caudal plasma.

FIG. 1, 2. - Paths followed by the heads of two spermatozoa with an irregular-circular movement. Fig. 3, 4. - Paths followed by the heads of two spermatozoa with a slow progression. Fig. 5, 6. Paths followed by the heads of two spermatozoa with an induced forward progression.

Epididymal plasma must be added to phosphodiesterase inhibitors in order to initiate forward progression. This study confirms the report of Brandt et al. (1978) and supports the idea that forward motility is initiated by a substance of epididymal origin.

Although phase-contrast microscopy showed caffeine stimulation and epididymal plasma to be satisfactory, the cinematographic study revealed that some induced sperm movements differed from the equivalent natural ones by the amplitude of the head movements. The initiated spermatozoa were able to move forward. The high concen- 
tration of caffeine necessary to stimulate them could induce this jerky movement, which might also partly result from the exhaustion of a great number of spermatozoa after one hour of incubation.

In conclusion, this study shows that the initiation of forward motility in immature hamster spermatozoa requires both CAMP phosphodiesterase inhibitors and epididymal plasma. The choice of the inhibitor and its concentration are important in inducing vigorous movement.

It remains to be demonstrated that forward moving spermatozoa from the caput epididymidis can fertilize ova, as shown by Shilon et al. (1978) in the guinea-pig. In vivo and/or in vitro fertilization with spermatozoa rendered artificially motile with caffeine and epididymal plasma should answer that question. However, before undertaking further experimentation, it is necessary to be able to maintain the initiated motility over a longer period.

Reçu en décembre 1979

Accepté en avril 1980.

Acknowledgements. - We are grateful to M. Gouzy and M. Le Dantec for their excellent technical assistance.

Résumé. Des spermatozoïdes de hamster, prélevés au niveau de la tête, du corps et de la queve de l'épididyme, placés à $37^{\circ} \mathrm{C}$ dans milieu de culture favorable à leur survie, sont observés au microscope à contraste de phase et leurs mouvements sont filmés à raison de 50 images par seconde. Le pourcentage de spermatozoïdes mobiles observés dans la tête de l'épididyme est de l'ordre de 20 p. 100. Ces spermatozoïdes bougent dans un espace restreint, sans aucun mouvement fléchant. Les spermatozoïdes du corps de l'épididyme montrent un accroissement dans leur mouvement flagellaire et se déplacent suivant une trajectoire circulaire. Le pourcentage de spermatozoïdes mobiles dans cette région est de 30 p. 100. Dans la queue de l'épididyme la majorité des spermatozoödes sont mobiles (90 p. 100). Ils se déplacent suivant un mouvement fléchant. Quelques fois l'on observe encore des trajectoires circulaires. L'action de différents inhibiteurs de la CAMP phosphodiestérase : théophylline, caféine, $I M X$, a permis d'induire le mouvement à partir de spermatozoïdes immobiles de la tête de l'épididyme. Toutefois, l'adjonction de plasma épididymaire est nécessaire pour obtenir l'initiation du mouvement fléchant. La meilleure stimulation est obtenue par l'action de $15 \mathrm{mM}$ de caféine associée à $10 \mathrm{p} .100$ de plasma épididymaire. Le pourcentage moyen de spermatozoïdes présentant un mouvement fléchant est dans ce cas de 60 p. 100 . Les études faites par microcinématographie ont montré que certains mouvements induits différaient des mouvements normalement observés par une plus grande amplitude des mouvements de la tête des spermatozoïdes. Ces résultats montrent que chez le hamster, au cours du transit épididymaire, le mouvement fléchanf est acquis dans la queue de l'épididyme. Ce mouvement peut être initié par augmentation de la teneur en CAMP des spermatozoïdes de la tête de l'épididyme, en présence de plasma épididymaire. Cette initiation est de courte durée ( $1 \mathrm{~h}$ maximale). L'hypothèse qu'une glycoprotéine d'origine épididymaire pourrait initier le mouvement fléchanł est discutée.

\section{References}

ACOTT T. S., JOHNSON D. J., BRANDT H., HOSKINS D. D., 1979. Sperm forward motility protein : tissue distribution and species cross-reactivity. Biol. Reprod., 20, 247-252.

BRANDT H., ACOTT T. S., JOHNSON D. J., HOSKINS D. D., 1978. Evidence for an epididymal origin of bovine sperm forward motility protein. Biol. Reprod., 19, 830-835.

CASCIERI M., AMANN R. P., HAMMERSTEDT R. H., 1976. Adenine nucleotide changes at initiation of bull sperm motility. J. biol. Chem., 10, 787-793. 
COURTENS J. L., FOURNIER-DELPECH S., 1979. Modifications in the plasma membranes of epididymal ram spermatozoa during maturation and incubation in ufero. J. ultrastruct. Res., 68, 136-148.

FLÉCHON J. E., 1975. Ultrastructural and cytochemical modifications of rabbit spermatozoa during epididymal transport, 36-45, In : E. S. E. HAFEZ, C. G. THIBAULT : The biology of spermatozoa. Transport, survival and fertilizing ability. Karger, Basel.

FOURNIER-DELPECH S., DANZO B. J., ORGEBIN-CRISTM. C., 1977. Extraction of concanavalin-A affinity material from rat testicular and epididymal spermatozoa. Ann. Biol. onim. Bioch. Biophys., 17, 207-213.

FRASER L. R., 1979. Accelerated mouse sperm penetration in vitro in the presence of caffeine. J. Reprod. Ferf., 57, 377-384.

GADDUM P., 1968. Sperm maturation in the male reproductive tract : development of motility. Anat. Rec., 161, 471-482.

GARBERS D. L., LUST W. D., FIRST N. L., LARDY H. A., 1971. Effects of phosphodiesterase inhibitors and cyclic nucleotides on sperm respiration and motility. Biochemistry, 10, 1825-1831.

GARBERS D. L., FIRST N. L., LARDY H. A., 1973. The stimulation of bovine epididymal sperm metabolism by cyclic nucleotide phosphodiesterase inhibitors. Biol. Reprod., 8, 589-598.

GARBERS D. L., FIRST N. L., GORMAN G. K., LARDY H. A., 1973. The effects of cyclic nucleotide phosphodiesterase inhibitors on ejaculated procine spermatozoa metabolism and fertility. Biol. Reprod., 8, 599-606.

GORDON M., DANDEKAR P. V., BARTOSZEWICZ W., 1974. Ultrastructural localization of surface receptors for concanavalin-A on rabbit spermatozoa. J. Reprod. Fert., 36, 211-214.

GORDON M., DANDEKAR P. V., BARTOSZEWICZ W., 1975. The surface coat of epididymal, ejaculated and capacitated sperm. J. ultrastruct. Res., 50, 199-207.

HOSKINS D. D., BRANDT H., ACOTT T. S., 1978. Initiation of sperm motility in the mammalian epididymis. Fed. Proc., 37, 2534-2542.

HOSKINS D. D., HALL M. L., MUNSTERMAN D., 1975. Induction of motility in immature bovine spermatozoa by cyclic AMP phosphodiesterase inhibitors and seminal plasma. Biol. Reprod., 13, 168-176.

HOSKINS D. D., STEPHENS D. T., HALL M. L., 1974. Cyclic adenosine 3'-5' monophosphate and protein kinase levels in developing bovine spermatozoa. J. Reprod. Ferf., 37, 131-133.

MENEZO Y., 1976. Milieu synthétique pour la survie et la maturation des gamètes et pour la culture de l'œuf fécondé. C. R. Acad. Sci. Paris, sér. D, 282, 1967-1970.

MORTON B., CHANG T. S. K., 1973. The effect of fluid from the cauda epididymis, serum components and caffeine upon the survival of diluted epididymal hamster spermatozoa. J. Reprod. Fert., 35, 255-263.

MORTON B., HARRIGAN-LUM J., ALBAGLI L., JOOSS T., 1974. The activation of motility in quiescent hamster cyclic nucleotides. Biochem. Biophys. Res. Commun. 56, 373-379.

MORTON B., SAGADRGA R., FRASER C., 1978. Sperm motility within the mammalian epididymis : species variation and correlation with free calcium levels in epididymal plasma. Fert. Steril., 29, 695-698.

NICOLSON G. L., USUI N., YANAGIMACHI R., YANAGIMACHI H., SMITH J. R., 1977. Lectinbinding sites on the plasma membranes of rabbit spermatozoa. Changes in surface receptors during epididymal maturation and after ejaculation. J. Cell Biol., 74, 950-962.

PAZ G. F., KAPLAN R., YEDWAB G., HOMONNAI Z. T., KRAICER P. F., 1978. The effect of caffeine on rat epididymal spermatozoa : motility, metabolism and fertilizing capacity. Int. J. Androl., 1, 145-152.

SHILON M., PAZ G., HOMONNAI Z. T., SCHOENBAUM M., 1978. The effect of caffeine on guinea pig epididymal spermatozoa : motility and fertilizing capacity. Int. J. Androl., 1, 416-423.

STEPHENS D. T., WANG J.-L., JOSKINS D. D., 1979. The cyclic AMP phosphodiesterase of bovin spermatozoa : multiple forms, kinetic properties and changes during development. Biol. Reprod., 20, 483-491.

YANAGIMACHI R., 1970. The movement of golden hamster spermatozoa before and after capacitation. J. Reprod. Fert., 23, 193-196. 